\title{
A distinctive childhood epilepsy syndrome
}

\author{
Indar Kumar Sharawat, Renu Suthar, ${ }^{\ominus}$ Naveen Sankhyan
}

Pediatric Neurology Unit, Department of Pediatrics, Post Graduate Institute of Medical Education and Research, Chandigarh, India

\section{Correspondence to}

Dr Renu Suthar, drrenusuthar@gmail.com

Accepted 18 April 2019

\section{DESCRIPTION}

A 9-year-old boy presented with recurrent stereotypic paroxysmal movements of upper limbs and head shaking for past 2 years. Each episode had an abrupt onset and termination and was characterised by a rhythmic jerking of arms, shoulders and the head. The event was associated with vacant stare and lasted for 5-30 s. These events were not associated with eyelid blinking, perioral twitching or loss of postural tone. He had complete amnesia for these events. The frequency of these events progressively increased to $15-20$ episodes per day. There was no recent change in behaviour, decline in school performance or any other affected family member. On examination, his anthropometry, neurological and systemic examination were unremarkable. During the clinical examination, the typical event was precipitated by hyperventilation (video 1). Ictal electroencephalogram showed generalised,

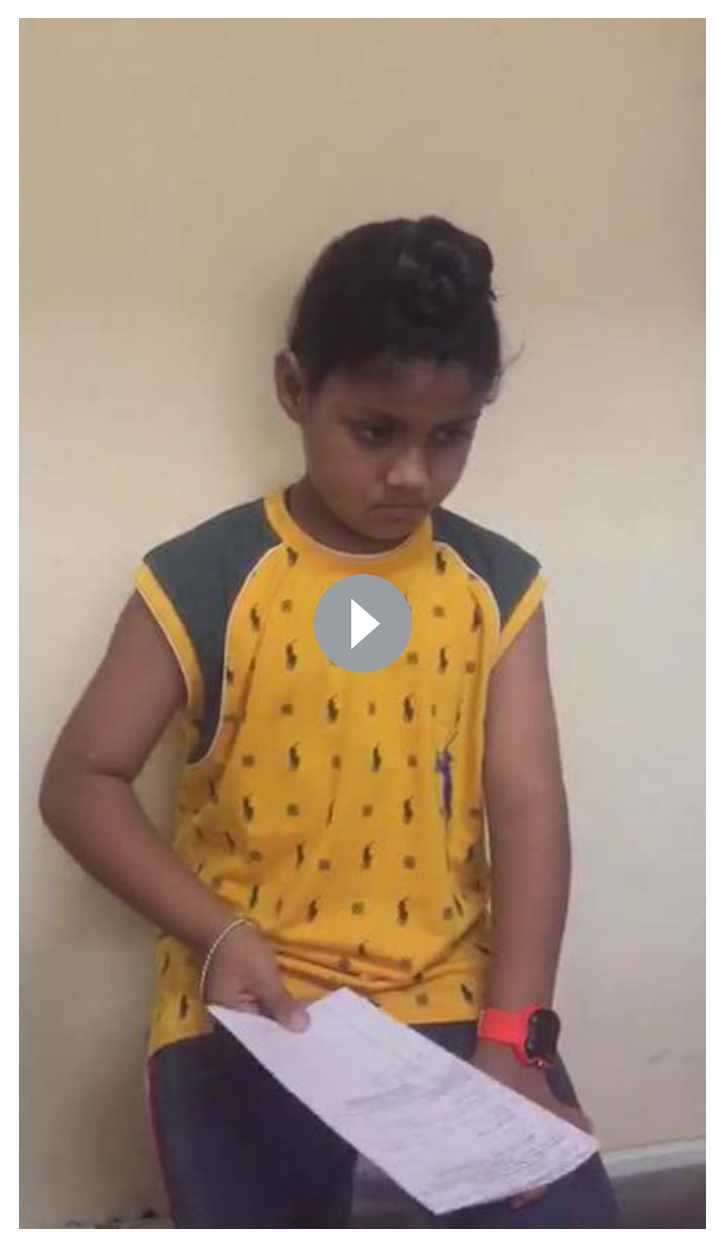

Video 1 The typical event was precipitated by hyperventilation and characterised by abrupt cessation of activity followed by jerks of upper limbs and head. Child had complete amnesia of the event.

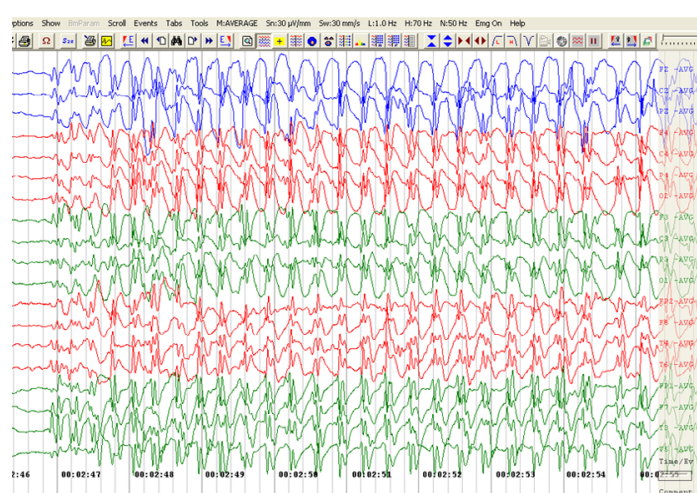

Figure 1 Awake ictal electroencephalogram (common average montage, sensitivity: $30 \mu \mathrm{V} / \mathrm{mm}$, sweep speed: $30 \mathrm{~mm} / \mathrm{s}$ ) showing abrupt onset of monomorphic bifrontal-dominant generalised 3- to $3.5-\mathrm{Hz}$ spike-andwave discharges with dart-and-dome that coincides with myoclonic jerks and has an abrupt offset.

synchronous $3 \mathrm{~Hz}$ spike and slow-wave discharge with abrupt onset and offset (figure 1). An electroclinical diagnosis of epilepsy with myoclonic absences (EMA) was considered. He attained good seizure control with sodium valproate $(25 \mathrm{mg} / \mathrm{kg} /$ day) and lamotrigine $(3 \mathrm{mg} / \mathrm{kg} /$ day $)$, and was seizure free till his last follow-up (16 months).

The syndrome of EMA is also called as the Tassinari syndrome. It was first described by Tassinari and colleagues ${ }^{1}$ in 1969 and characterised by jerks of limbs, head or both with loss of awareness. The peak age of the onset of seizures is 3-7 years. Affected children have normal intellect before the onset of seizures, but most of the children have cognitive slowing or school difficulties after the onset of symptoms. ${ }^{2}$ Few children may also have generalised tonic-clonic seizures. The frequency of myoclonic absences varies from 1 to 100 episodes per day and they can be precipitated by hyperventilation. Ictal EEG typically shows generalised spikewave discharges of $3-3.5 \mathrm{~Hz}$ frequencies. ${ }^{3}$ Distinct

\section{Learning points}

Tassinari syndrome also called as epilepsy with myoclonic absences and is characterised by jerks of limbs, head or both with loss of awareness.

- Affected children have normal intellect before the onset of seizures, but most of them have cognitive slowing or school difficulties after the onset of symptoms.

- The long-term prognosis of Tassinari syndrome is guarded and most of the individuals require polytherapy. 
from other genetic generalised epilepsies, the long-term prognosis is guarded and most of the individuals require polytherapy with valproic acid, ethosuximide, lamotrigine, levetiracetam and benzodiazepines. ${ }^{2}$

Contributors IKS: patient management, literature review and initial draft of manuscript preparation. RS: patient management, critical review of manuscript for important intellectual content and final approval of the version to be published. NS: clinician-in-charge, critical review of manuscript for important intellectual content and final approval of the version to be published.

Funding The authors have not declared a specific grant for this research from any funding agency in the public, commercial or not-for-profit sectors.

Competing interests None declared.
Patient consent for publication Parental/guardian consent obtained.

Provenance and peer review Not commissioned; externally peer reviewed.

\section{REFERENCES}

1 Tassinari CA, Lyagoubi S, Santos V, et al. Etude des de'charges de pointes ondes chez I'homme. II: Les aspects cliniquesee'lectroence'phalographiques des absences myocloniques. Rev Neurol 1969;121:379-83.

2 Manonmani V, Wallace SJ. Epilepsy with myoclonic absences. Arch Dis Child 1994:70:288-90

3 Zanzmera P, Menon RN, Karkare K, et al. Epilepsy with myoclonic absences: Electroclinical characteristics in a distinctive pediatric epilepsy phenotype. Epilepsy Behav 2016;64:242-7.

Copyright 2019 BMJ Publishing Group. All rights reserved. For permission to reuse any of this content visit

https://www.bmj.com/company/products-services/rights-and-licensing/permissions/

BMJ Case Report Fellows may re-use this article for personal use and teaching without any further permission.

Become a Fellow of BMJ Case Reports today and you can:

- Submit as many cases as you like

- Enjoy fast sympathetic peer review and rapid publication of accepted articles

- Access all the published articles

Re-use any of the published material for personal use and teaching without further permission

For information on Institutional Fellowships contact consortiasales@bmjgroup.com

Visit casereports.bmj.com for more articles like this and to become a Fellow 